\title{
Soybean (Glycine max L.) seed quality treated with timbó (Magonia pubescens A.St.-Hil) seed coat
}

\section{Qualidade de sementes de soja (Glycine max L.) tratadas com diasporo do tegumento de sementes de timbó (Magonia pubescens A.St.-Hil)}

\author{
Ana Mayra Pereira Silva ${ }^{1 *}$ (1) (orcid.org/0000-0002-5643-2692) \\ Amanda Ribeiro Correa' (1D) (orcid.org/0000-0002-2468-6073) \\ Cárita Rodrigues de Aquino Arantes ${ }^{1}$ (1) (orcid.org/0000-0003-1148-4517) \\ Rosiane Alexandre Pena Guimarães ${ }^{1}$ (1) (orcid.org/0000-0002-4259-6215) \\ Maria de Fátima Barbosa Coelho' ${ }^{1}$ (1) (orcid.org/0000-0003-1393-2504) \\ Elisangela Clarete Camili ${ }^{1}$ (1) (orcid.org/0000-0002-4642-2511) \\ Leimi Kobayasti' ${ }^{1}$ (1) (orcid.org/0000-0003-1077-5240)
}

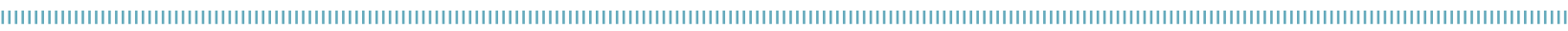

\begin{abstract}
The objective of this study was to evaluate the effect of timbó seed coat on the physiological and sanitary quality of soybean seeds. Timbó seeds were collected from mature fruits in the Cerrado. The external layer of the seed coat was removed and crushed in a mill and used in the treatment of soybean seeds. Three lots of soybean seeds were used, from high, medium and low vigor seeds. The treatments were: powder; gel; hydroalcoholic extract; synthetic fungicide (Vitavax ${ }^{\circledR}$ Thiram $200 \mathrm{sc}$ ), and untreated seeds. The physiological quality of the soybean seeds was determined by standard germination, accelerated aging, length, fresh and dry mass of seedlings. Blotter test was used to determine the sanitary quality. The statistical analyze used was a completely randomized $3 \times 5$ factorial design, considering three seed lots and five treatments. Treatment with the coat seed extract and gel improves the physiological quality of soybean seeds from low vigor lots. The treatment of seeds with gel decreases the incidence of Fusarium and Penicillium genus; and treatment with the powder reduced the incidence of the Cercospora genus.
\end{abstract}

KEYWORDS: physiological quality; sanitary quality; seed vigor; alternative treatment; natural extract.
RESUMO: O objetivo deste estudo foi avaliar o efeito do tegumento das sementes de timbó sobre a qualidade fisiológica e sanitária de sementes de soja. As sementes de timbó foram coletadas de frutos maduros, no Cerrado. A camada mais externa do tegumento das sementes foi retirada e triturada em moinho e utilizada no tratamento de sementes de soja. Foram utilizados três lotes de sementes de soja, provenientes de sementes de alto, médio e baixo vigor. Os tratamentos foram: pó, gel, extrato hidroalcoólico; fungicida sintético $\left(\right.$ Vitavax $^{\circledast}$ - Thiram 200 sc) e sementes não tratadas. A qualidade fisiológica das sementes de soja foi determinada pelo teste padrão de germinação, envelhecimento acelerado, comprimento, massa fresca e seca de plântulas. Para a determinação da qualidade sanitária utilizou-se o teste de borrão (blotter test). O delineamento estatístico foi em esquema fatorial $3 \times 5$, inteiramente casualizado, considerando-se três lotes de sementes e cinco tratamentos. Os tratamentos com o extrato e o gel do tegumento das sementes de timbó melhoraram a qualidade fisiológica das sementes de soja provenientes de lotes de baixo vigor. O tratamento com gel do tegumento das sementes de timbó diminuiu a incidência de fungos dos gêneros Fusarium e Penicillium; e o tratamento com o pó reduziu a incidência do gênero Cercospora.

PALAVRAS-CHAVE: qualidade fisiológica; qualidade sanitária; vigor de sementes; tratamento alternativo; extrato natural. 


\section{INTRODUCTION}

Crop success depends of several factors and the most important is the use of high quality seeds, as it generates plants of high vigor and a superior performance in the field (FRANÇA NETO et al., 2016).

To enable plants with vigorous growth and obtain a better use of the productive potential of the plants, treatment of seeds with fungicides is a recommended practice. It provides a better establishment of plant populations by controlling important pathogens transmitted by seeds (HENNING, 2018).

Seed treatment is usually carried out by synthetic fungicides with different active ingredients; however, new molecules are constantly studied, including those from natural sources, such as plant extracts and essential oils (DOMENE et al., 2016).

A series of molecules with antifungal activity against different strains of fungi have been detected in plants; these molecules can be used directly or considered as precursors for the development of better molecules (ARIF et al., 2009). DUKE et al. (2010) highlight that natural products have advantages in order to improve physiological seed quality, cause less environmental impact when compared to synthetic agrochemicals, and can also reveal molecules with potential to be used in synthesis of new commercial antifungals.

For timbó species, there are reports of the use of leaf extract and hydrogel, formed by the external layer of seed coat, in the control of their own fungi, as well as the effect of powder application of timbó seed coat on initial development of cucumber seeds (Cucumis sativus).

Still, it is possible to identify the study with different parts of the Magonia pubescens plant on the development of Aedes aegypti larvae (SILVA et al, (2004); ARRUDA et al, (2003)). OLIVEIRA et al. (2001) when analyzing the photochemical profile of the timbó seed coat, detected the presence of carbohydrates, phenolic compounds, acidic material, and cellulose. These compounds are reported in the literature with high fungitoxic potential.

STANGARLIN et al. (2011) reports that phenolic compounds have an inhibitory effect on spore germination and mycelial growth of phytopathogens; these compounds act directly on the mitochondria, wall, and cell fungi membrane (LAGROUH et al., 2017).

Thus, timbó seed coat can be an alternative to control phytopathogenic fungi and increase the vigor of soybean seeds. In this case, the research aimed to evaluate the effect of timbó seed coat on the physiological and sanitary quality of soybean seeds.

\section{MATERIAL AND METHODS}

This work was carried out at the Seed and Phytopathology Laboratories of Federal University of Mato Grosso, campus Cuiabá/MT. Three soybean seed lots (high, medium, and low vigor) of cultivar M8372-IPRO produced in the 2017/18 crop were evaluated. The seeds were received in May 2018.

For the initial characterization of the three soybean seed lots, water content and germination percentage were determined according to the methodologies established by the Rules for Seed Analysis-RAS (BRASIL, 2009a).

Soybean seeds lots with high, medium, and low vigor presented $10.7,10.4$, and $10.8 \%$ of water content and 97,91 , and $87.5 \%$ of germination respectively. Therefore, they were presented with low humidity and germination above the minimum of $85 \%$ established by Normative Instruction No. 45 of the Ministry of Agriculture, Livestock, and Supply (MAPA).

After the initial characterization, seed lots were stored in a refrigerated chamber at $17 \pm 2^{\circ} \mathrm{C}$ and $60 \pm 4 \%$ of relative air humidity, throughout the conduction of the experiments.

Timbó seeds were collected from ripe fruits in September of 2017 in Cerrado areas of Baixada Cuiabana, in the Mato Grosso State. The annual average temperature of location is $27.4^{\circ} \mathrm{C}$ and precipitation of $135 \mathrm{~mm}$ (INMET, 2018).

External layer (second layer) of timbó seeds coat was removed with the aid of a scalpel, which was then crushed in a knife mill. The vegetable material of coat was used in assessing physiological quality and health of soybean seeds.

Analysis of macro and micronutrients present in the timbó seed coats was carried out according to the methodology proposed by MALAVOLTA et al. (1997). Macronutrients identified were: $\mathrm{N}=3.5 ; \mathrm{P}=0.5 ; \mathrm{K}=30.8 ; \mathrm{Ca}=1.9 ; \mathrm{Mg}=0.8$, and $\mathrm{S}=0.1 \mathrm{~g} \mathrm{~kg}^{-1}$, and micronutrients: $\mathrm{Zn}=8.2 ; \mathrm{Cu}=2.2$; $\mathrm{Fe}=57.4 ; \mathrm{Mn}=17.4$, and $\mathrm{B}=12.9 \mathrm{mg} \mathrm{kg}^{-1}$.

Qualitative identification of timbó seed coat compounds was determined by method proposed by MATOS (2009), placing $50 \mathrm{~g}$ of powder of timbó seed coat in $500 \mathrm{~mL}$ of alcohol $(70 \%)$ and maceration for three days on amber glass at $17 \pm 2^{\circ} \mathrm{C}$. Then, hydroalcoholic extract was filtered and the solvent was extracted by rotavapor, and the results were expressed qualitatively. The presence of phenols, tannins, flavonoids, triterpenes, and saponins was identified in the chemical composition of the timbó seed coat powder.

Treatments of the soybean seed lots were carried out as described below. For the treatment with hydroalcoholic extract, the same extraction procedure was performed for qualitative identification of chemical compounds of timbó seed coat and $300 \mathrm{~mL}$ of the extract for $100 \mathrm{~kg}$ of seeds was applied.

For gel treatment, $2 \mathrm{~g}$ of the timbó seed coat in $100 \mathrm{~mL}$ of distilled water was added and then the gel formed was applied directly to the soybean seeds at $300 \mathrm{~mL}$ of the extract for $100 \mathrm{~kg}$ of seeds.

In the treatment with the timbó seed powder, an adhesive polymer (Polyseed $\mathrm{CF}^{\oplus}$ ) was first applied in the proportion of $40 \mathrm{~mL}$ of the polymer for $100 \mathrm{~kg}$ of seeds and then the timbó seed powder was applied in the proportion of $200 \mathrm{~g}$ of tegument powder for $100 \mathrm{~kg}$ of seeds. For the fungicide 
treatment, the chemical Vitavax ${ }^{\circledR}$ - Thiram 200 sc (carboxine + thiram) was applied, according to the recommendations contained in the package insert.

As a control, soybean seeds were evaluated without neither treatment.

After the treatments were carried out on the seeds, they were placed on absorbent paper for drying, for a period of $24 \mathrm{~h}$, at a temperature of $\pm 27^{\circ} \mathrm{C}$ and $\pm 55 \%$ of $\mathrm{RH}$.

The physiological quality of soybean seeds was determined by the germination pattern, accelerated aging, length, fresh and dry seedling mass. Blotter test was used to determine sanitary quality.

The first germination count was evaluated together with the germination test, counting the normal seedlings on the fifth day after sowing and the data were expressed as a percentage (BRASIL, 2009a). Germination test was conducted with four replications of 50 seeds from each lot. The seeds were placed to germinate on a germination paper substrate ("germitest"), moistened with distilled water in the proportion of 2,5 the mass of dry paper, and then placed in BOD incubators, at a constant temperature of $25^{\circ} \mathrm{C}$ with 12 hours of photoperiod. Evaluations of germinated seeds were carried out on the eighth day, according to the criteria established by the Rules for Seed Analysis-RAS (BRASIL, 2009a).

For germination speed index (GSI), the number of normal seedlings obtained in the germination test was recorded daily, until stabilization. Calculations of GSI was made according to the formula proposed by MAGUIRE (1962). The seeds were considered germinated when they had at least $2 \mathrm{~mm}$ of primary root. For the accelerated aging test, the methodology proposed by KRZYZANOWSKI et al. (1999) was used.

Forty $\mathrm{mL}$ of distilled water were added to "gerbox" acrylics boxes. Then, samples of seeds from each treatment were distributed on metallic screens in a single layer and coupled inside the boxes at a distance of $1.5 \mathrm{~cm}$ from the water. The boxes were covered and taken to a B.O.D. incubator at temperature of $41^{\circ} \mathrm{C}$ for 48 hours (KRZYZANOWSKI et al., 1999). After accelerated aging, the seeds were submitted to the germination test. Count of normal seedlings was performed on the fifth day after sowing (BRASIL, 2009a).

Length and shoot and root fresh masses of normal seedlings were evaluated with four repetitions of 10 seeds per treatment, in germination paper rolls. The paper was moistened as described in the germination test and the rolls were packed in sealed plastic boxes to prevent loss of moisture and kept in B.O.D. at $30 \pm 1^{\circ} \mathrm{C}$ in total dark to eliminate the effect of luminosity.

On the seventh day after sowing, normal seedlings were measured with a ruler graduated in millimeters, obtaining the length of the aerial part and root (NAKAGAWA, 1999).

Fungal incidence in soybean seeds was evaluated using the filter paper method (blotter test), as described in the Manual of Sanitary Analysis of Seeds (BRASIL, 2009b).
For each treatment, eight Petri dishes with 25 seeds each were used, distributed over three filter paper previously moistened with sterilized $\mathrm{NaCl}$ solution at $-1.0 \mathrm{Mpa}$ (CELANO et al., 2012). Seeds were remained at a temperature of $20 \pm$ $2^{\circ} \mathrm{C}$ with a photoperiod of 12 hours of light for seven days (BRASIL, 2009b).

Statistical design used was in a $3 \times 5$ factorial scheme, considering three seed lots and five treatments with four replications. Analysis of variance was performed, and the treatment means compared by the Tukey test $(\mathrm{p}<0.05)$. All analyzes were performed using statistical program SISVAR 5.6 (Build 86) (FERREIRA, 2015).

\section{RESULTS AND DISCUSSION}

Differences in all analyzed variables were obtained of high, medium, and low vigor of soybean seed lots. Different treatments applied to the seeds showed significant effects, except for germination percentage, and the interaction effect was not significant for germination percentage.

In germination percentage $(\mathrm{G})$, as expected, the high lot vigor stood out, followed by medium and low vigor lots, respectively (Table 1). As there was no effect of treatments or interaction, it is possible to infer that the use of timbó seed coat to treat soybean seeds does not present negatively effect on the percentage of germinated seeds.

The first germination count shows that the high vigor lot was superior when compared to the medium and low vigor ones. However, for the medium vigor lot, the treatments with extract, gel, and powder were superior to the performance presented by the fungicide and, in turn, it did not differ from the witness (Table 2). Regarding the comparisons between treatments within each seed lot, it was observed that, in the high vigor lot, treatments did not differ among themselves; in the case of medium and low vigor seeds, the use of timbó tegument in the form of gel was responsible for accelerating the germination of soybean seeds, although it did not differ from the treatments with extract, powder, and witness in the case of low seeds vigor (Table 2).

Table 1. Germination percentage of soybean seeds (Glycine max L.) treated with timbó seed coat (Magonia pubescens $A$. St. - Hil). UFMT, Cuiabá, MT, 2018.

\begin{tabular}{lc} 
Lot (vigor) & Germination \\
\hline High & $98.8^{*} \mathrm{~A}$ \\
\hline Medium & $96.6 \mathrm{~B}$ \\
\hline Low & $94.3 \mathrm{C}$ \\
\hline CV (\%) & 2.23 \\
\hline
\end{tabular}

*Averages followed by the same letter do not differ by Tukey's test at $5 \%$ of probability. 
In this initial period, there is intense absorption of water by seeds, which facilitates the digestion, mobilization, and assimilation of reserves contained in them (MARCOS FILHO, 1986). Treatments used with extract, gel, and powder and gel for medium and low vigor batches, respectively, provided greater water availability in the imbibition process and favored the vigor of soybean seeds in medium and low vigor lots (Table 2).

In comparison with control, gel, extract, and powder in the medium vigor lot contributed with an increase of 10.6, 9.0 , and $8.0 \%$ at the first germination count, respectively; in the low vigor lot, the gel increased germination in the first count by $2.6 \%$ (Table 2 ).

Regarding the germination speed index (GSI), in medium and low vigor lots, fungicide and gel, and gel and powder, respectively, improved the seed germination speed when compared to the other treatments. However, in the high vigor lot, no treatment differed from the control (Table 2).

In this way, the treatment with gel can provide physiological conditioning in low-vigor soybean seeds, as they are rich in carbohydrates (OLIVEIRA et al., 2001) and are used in formation of structural components during seedling growth (ZIEGLER, 1995). In addition, they may be used as a substrate for breathing during the pre-germination period (BEWLEY; BLACK, 1994).

When analyzing chemical composition of powder of the timbó seed coat, it was observed the presence of alkaloids, flavonoids, saponins, phenolic constituents, and carbohydrates. These compounds were also observed by LINS et al. (2012) in the Momordica charantia extract. MEDEIROS et al. (2013) observed a better performance in the germination percentage of Pterogyne nitens seeds treated with Momordica charantia and Allamanda blanchetti extract. In this sense, these compounds may have favored the performance of low vigor soybean seeds when treated with gel and powder from timbó seed coat.

Soybean seed germination from the high vigor lots submitted to the accelerated aging test (AE) shows that, when treated with timbó seed coat and untreated (control), there was no difference, and the treatments with extract and gel of timbó seed coat caused allelopathic effect and reduced the germinative potential of soybean seeds. In the case of medium vigor lot, the highest average of germinated seeds was obtained when treated with gel and, in the low vigor lot, fungicide treatment was the most successful, followed by gel (Table 3).

The greater availability of water provided by gel treatment of timbó seed coat for medium vigor seed lot probably reduced the harmful effects caused by fungi in the stress of accelerated aging, since high temperatures and humidity can inhibit the manifestation of some microorganisms present in soybean seeds (MARCOS FILHO, 1994).

The gel treatment of timbó seed coat improved $10 \%$ of germination percentage of the seeds in the medium vigor lot, compared with the control. In the low vigor lot, although the fungicide stood out, timbó seed coat gel increased germination by $5.3 \%$ and differed statistically from the control (Table 3 ). This fact represents a gain in the physiological and sanitary quality of soybean seeds.

Seedlings of low vigor lot showed greater lengths, in relation to those of high and medium vigor, except when compared to the control of the high and low vigor lots. In general,

Table 3. Germination percentage in the accelerated aging test (AE) of soybean seeds (Glycine max L.), cultivar M8372-IPRO, from high, medium and low vigor lots, treated with timbó seed coat (Magonia pubescens A. St. - Hil). UFMT, Cuiabá, MT, 2018.

\begin{tabular}{lccc} 
Trat / Lots & \multicolumn{3}{c}{ AE } \\
\cline { 2 - 4 } & High & Medium & Low \\
Extract & $78.0^{*} \mathrm{Bc}$ & $86.0 \mathrm{Ab}$ & $76.4 \mathrm{Bc}$ \\
\hline Gel & $86.0 \mathrm{Bb}$ & $94.0 \mathrm{Aa}$ & $84.6 \mathrm{Bab}$ \\
\hline Powder & $94.5 \mathrm{Aa}$ & $80.0 \mathrm{Bb}$ & $80.6 \mathrm{Bb}$ \\
\hline Fungicide & $84.6 \mathrm{Ab}$ & $82.6 \mathrm{Ab}$ & $86.0 \mathrm{Aa}$ \\
\hline Control & $94.0 \mathrm{Aa}$ & $84.0 \mathrm{Bb}$ & $79.3 \mathrm{Bbc}$ \\
\hline CV (\%) & & 3.57 & \\
\hline
\end{tabular}

*Averages followed by the same lowercase letter in the column and uppercase in the lines do not differ by Tukey's test at $5 \%$ of probability.

Table 2. First count (FC) and germination speed index (GSI) of soybean seeds (Glycine max L.), M8372-IPRO cultivar, from high, medium and low vigor lots, treated with timbó seed coat (Magonia pubescens A. St. - Hil). UFMT, Cuiabá, MT, 2018.

\begin{tabular}{lccccccc} 
& \multicolumn{3}{c}{ FC } & & & \multicolumn{2}{c}{ GSI } \\
\cline { 2 - 7 } Trat / Lots & High & Medium & Low & High & Medium & Low \\
\cline { 2 - 8 } Extract & $94.0^{*} \mathrm{Aa}$ & $87.0 \mathrm{Ba}$ & $89.3 \mathrm{Bab}$ & $40.4 \mathrm{Aa}$ & $32.3 \mathrm{Bcd}$ & $32.7 \mathrm{Bb}$ \\
\hline Gel & $96.0 \mathrm{Aa}$ & $88.6 \mathrm{Ba}$ & $92.6 \mathrm{Aa}$ & $35.3 \mathrm{Ac}$ & $35.0 \mathrm{Ab}$ & $36.1 \mathrm{Aa}$ \\
\hline Powder & $96.0 \mathrm{Aa}$ & $86.0 \mathrm{Bab}$ & $89.3 \mathrm{Bab}$ & $37.3 \mathrm{Abc}$ & $33.1 \mathrm{Bbc}$ & $35.2 \mathrm{Aab}$ \\
\hline Fungicide & $96.5 \mathrm{Aa}$ & $83.2 \mathrm{Cb}$ & $88.6 \mathrm{Bb}$ & $38.1 \mathrm{ABb}$ & $39.6 \mathrm{Aa}$ & $35.7 \mathrm{Ba}$ \\
\hline Control & $95.5 \mathrm{Aa}$ & $78.0 \mathrm{Cc}$ & $90.0 \mathrm{Bab}$ & $38.4 \mathrm{Aab}$ & $30.7 \mathrm{Cd}$ & $35.7 \mathrm{Ba}$ \\
\hline CV (\%) & & 2.86 & & & 4.28 &
\end{tabular}


it is possible to observe a better performance of the seeds when treated with extract and gel obtained from the seed coat of timbó seeds, regardless of the vigor of the soybean seed lots (Table 4).

TAVALLALI et al. (2009) report that zinc can improve carbonic anhydrase, which is very beneficial to plants, in order to facilitate the supply of $\mathrm{CO}_{2}$ from the stomatal cavity to the $\mathrm{CO}_{2}$ fixation site and thus increase the overall growth of plants.

On the other hand, LOPES (1998) indicates that zinc and manganese are micronutrients directly related to the photosynthetic reactions and plant growth. Therefore, these micronutrients are present in the seed coat of timbó and may be more readily available or in greater concentration, and this favored the observed performance (Table 4).

Shorter aerial part length in the high and medium vigor seed lots can be attributed to the high physiological potential of the seeds, since their nutritional requirements was supplied, and the treatments with extract, gel, and powder of the timbó seed coat for this lot may have caused phytotoxic effect, due to excess nutrition. When testing the influence of zinc stress on tomato plants (Solanum lycopersicum), CHERIF et al. (2010) indicated that plants treated with $10 \mu \mathrm{M}$ zinc showed better growth, however higher doses affected their physiological potential.
As for the length of the seedling root, the extract provided better performance in relation to the other treatments used in the seeds of medium and low vigor lots (Table 4). According to VIGNOLO et al. (2014), certain phenolic compounds interact with auxins and induce initiation of root growth, that is, the presence of phenolic compounds in the seed coat of timbó seeds favored the availability of nutrients, in comparison with powder treatments and gel.

Significant additions were observed for the fresh weight of aerial part obtained from low vigor soybean seeds, when treated with timbó seed coat extract and gel. However, when comparing with the control, the use of timbó seed coat gel, in the high and medium vigor lots, were superior to the others and did not differ from the control. In the medium vigor lot, they did not differ from the use of powder (Table 5). In this way, we can prove the allelopathic effect of the treatment with timbó seed coat extract for the seeds of the high and medium vigor lot.

As for the fresh root seedling mass, treatments with tegument extract from timbó seeds and fungicide from the seeds of low vigor lot presented a better performance than the others. In the high vigor lot, the fresh weight of seedling roots obtained from seeds treated with tegument extract from timbó and fungicide seeds was lower when compared to the other

Table 4. Length of aerial part (LAP) and root (LR) of seedlings obtained in a germination paper, from soybean seeds (Glycine max L.) cultivar M8372-IPRO, from high, medium lots and low vigor, treated with timbó seed coat (Magonia pubescens A. St. - Hil). Cuiabá, MT, 2018.

\begin{tabular}{lccccccc} 
& & LAP $(\mathrm{cm})$ & & & \multicolumn{2}{c}{ LR $(\mathrm{cm})$} \\
\cline { 2 - 7 } Trat / Lots & High & Medium & Low & High & Medium & Low \\
\hline Extract & $12.6^{*} \mathrm{Ca}$ & $13.2 \mathrm{Ba}$ & $14.8 \mathrm{Aa}$ & $12.3 \mathrm{Bb}$ & $13.0 \mathrm{Ba}$ & $16.0 \mathrm{Aa}$ \\
\hline Powder & $12.5 \mathrm{Ca}$ & $13.3 \mathrm{Ba}$ & $14.3 \mathrm{Aa}$ & $11.9 \mathrm{Ac}$ & $12.2 \mathrm{Aab}$ & $12.4 \mathrm{Ac}$ \\
\hline Fungicide & $11.2 \mathrm{Cb}$ & $12.1 \mathrm{Bb}$ & $13.4 \mathrm{Ab}$ & $12.0 \mathrm{Ac}$ & $11.4 \mathrm{Ab}$ & $10.7 \mathrm{Bd}$ \\
\hline Control & $11.2 \mathrm{Cb}$ & $12.0 \mathrm{Bb}$ & $13.3 \mathrm{Ab}$ & $13.4 \mathrm{Ba}$ & $12.6 \mathrm{Ba}$ & $14.5 \mathrm{Ab}$ \\
\hline CV $(\%)$ & $12.9 \mathrm{Aab}$ & $12.5 \mathrm{Bb}$ & $13.3 \mathrm{Ab}$ & $13.0 \mathrm{Aab}$ & $11.7 \mathrm{Ab}$ & $11.4 \mathrm{Bd}$ \\
\hline
\end{tabular}

*Averages followed by the same lowercase letter in the column and uppercase in the lines do not differ by Tukey's test at $5 \%$ probability.

Table 5. Fresh mass of aerial part (FMAP) and roots (FRM) of seedlings obtained on a germination paper, from soybean seeds (Glycine max L.) cultivar M8372-IPRO, from high, medium and low vigor seed lots, treated with timbó seed coat (Magonia pubescens A. St. - Hil). Cuiabá, MT, 2018.

\begin{tabular}{lccccccc} 
& & \multicolumn{3}{c}{ FMAP } & & \multicolumn{3}{c}{ FMR } \\
\cline { 2 - 7 } Trat / Lots & High & Medium & Low & High & Medium & Low \\
\cline { 2 - 8 } Extract & $6.5^{*} \mathrm{Bb}$ & $6.9 \mathrm{Bab}$ & $8.1 \mathrm{Aa}$ & $1.03 \mathrm{Bb}$ & $0.93 \mathrm{Cc}$ & $1.31 \mathrm{Aa}$ \\
\hline Gel & $7.4 \mathrm{Aa}$ & $7.4 \mathrm{Aa}$ & $7.8 \mathrm{Aa}$ & $1.15 \mathrm{Aa}$ & $1.04 \mathrm{Bb}$ & $0.92 \mathrm{Cb}$ \\
\hline Powder & $6.0 \mathrm{Ab}$ & $6.2 \mathrm{Ac}$ & $6.0 \mathrm{Ad}$ & $1.11 \mathrm{Aab}$ & $0.88 \mathrm{Bc}$ & $0.74 \mathrm{Cc}$ \\
\hline Fungicide & $6.3 \mathrm{Bb}$ & $6.8 \mathrm{ABb}$ & $7.0 \mathrm{Ab}$ & $1.14 \mathrm{Ba}$ & $0.92 \mathrm{Cc}$ & $1.27 \mathrm{Aa}$ \\
\hline Control & $7.5 \mathrm{Aa}$ & $7.5 \mathrm{Aa}$ & $6.5 \mathrm{Bc}$ & $1.17 \mathrm{Aa}$ & $1.12 \mathrm{Aa}$ & $0.91 \mathrm{Bb}$ \\
\hline CV $(\%)$ & & 4.90 & & & 6.95 & & \\
\hline
\end{tabular}

*Averages followed by the same lowercase letter in the column and uppercase in the lines do not differ by Tukey's test at $5 \%$ probability. 
treatments. In the case of medium vigor seeds, control stood out in relation to all seed treatments (Table 5).

This may have occurred due to the interaction in the absorption of nutrients present in the extract of timbó seeds coat for low vigor lot, since the deteriorated seeds have greater membrane permeability (BEWLEY; BLACK, 1994), and have higher absorption rates in the first hours of the imbibition process (SILVA; VILLELA, 2011). Therefore, they have a greater capacity for contact with macro and micronutrients, giving them greater performance in the aerial part length and fresh aerial and root part mass (Tables 4 and 5).

In the evaluation of sanitary quality of soybean seeds, there was significance of isolated factors (lots and treatments) and of interaction (lots $\times$ treatments) for fungi Cercospora sp., Fusarium spp., Penicillium sp. and Cladosporium spp. (Figure 1).

According to the results observed in Figure 1, for the Cercospora sp. fungi, in the low vigor seed lot, lowest fungal incidence was obtained when the soybean seeds were treated with timbó seed coat powder or fungicide, and did not differ of the high and medium vigor lots for the treatment with fungicide, which controlled $100 \%$ of the incidence.

When comparing treatments with control in the high vigor lots, extracts of timbó seed coat, fungicide, gel, and powder of timbó seed coat reduced $75,100,33$, and $66 \%$ of incidence of Cercospora sp. In the low vigor lots, inhibition was $75,100,65$, and $100 \%$, respectively, in relation to the control. Medium vigor lots did not show statistical difference between treatments, with an average of $32 \%$ of incidence, except for fungicide treatment, where the control was $100 \%$.

Observing results for Fusarium spp. in the three soybean seed lots, fungicide treatment resulted in the lowest percentages and it did not differ from the treatments with gel and powder, extract and gel, and from the control, in the high, medium, and low vigor lots, respectively (Fig. 1).

In relation to the control, all treatments used in the seeds of medium vigor lot reduced fungal incidence of Fusarium spp. However, there was an increase in the incidence of Fusarium spp. in the low vigor seed lots treated with the timbó coat seed, that is, the incidence was significantly higher in this treatment than in the control (Fig. 1).

Results obtained by CAMILI et al. (2009), when evaluating basidiocarp extract on the mycelial growth of Botrytis cinerea and Agaricus blazei, demonstrated that the extracts stimulated the mycelial growth and spore germination of microorganisms in doses higher than $2.5 \%$ significantly.

Studies by MONTEIRO et al. (2005) to evaluate chemical composition of mushroom Agaricus sp. observed the presence of high content of iron, zinc, potassium, and phosphorus, which are compounds present in the chemical composition of timbó seed coat.

For Penicillium sp., it is observed that the treatment with fungicide controlled $100 \%$ of pathogen incidence. In the low vigor seed lot, treatments with gel and fungicide did not differ (Fig. 1).

For Cladosporium spp. fungus, the fungicide differed from other treatments in the three soybean seed lots evaluated and resulted in $100 \%$ of control (Fig. 1).
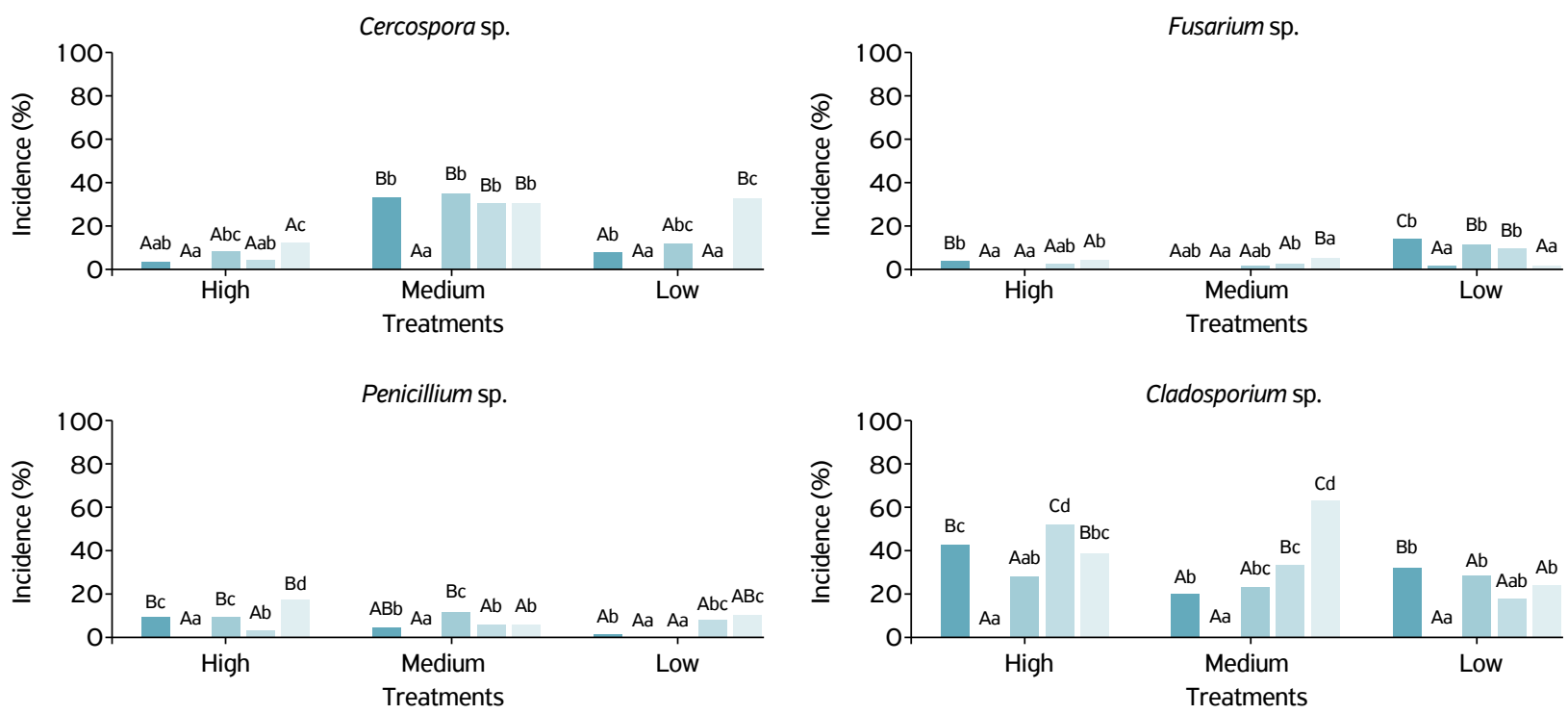

Extract

Gel Powder

Fungicide

Control

Means followed by equal capital letters, for comparison of equal treatments between batches, and lower-case letters, for comparison between treatments within batches, do not differ by Tukey's test at $5 \%$ probability $(P<0.05)$.

Figure 1. Fungal incidence (\%) in soybean seeds (Glycine max L.) of cultivar M8372-IPRO from high, medium and low vigor lots, treatments with timbó seed coat (Magonia pubescens A. St. - Hil). Cuiabá, MT, 2018. 
Comparing the control results with the other treatments in the high vigor lots, show a $28 \%$ of reduction in the incidence of Cladosporium spp. on seeds treated with gel. In medium vigor seed lot, treatments with extract and gel were the most efficient among the forms of application of timbó seed coat and reduced 68 and $63 \%$ of Cladosporium spp. incidence, respectively, in relation to the control (Fig. 1).

The results observed with treatments employed reinforce the need for further research to recommend timbó seed coat in different applications, isolated compounds, or a synthetic product with the characteristics of isolate, in the seed treatment. However, it is clear that timbó seed coat is an alternative product for control of some fungi associated with soybean seeds and also acts as a seedling growth promoter.

\section{CONCLUSIONS}

Treatments with extract and gel of timbó seed coat improve physiological quality of soybean seeds from low vigor seed lots.

Treatment of soybean seeds with timbó seed coat gel reduces incidence of fungi of Fusarium and Penicillium genus; and the treatment with powder reduce incidence of fungi of Cercospora genus.

ACKNOWLED GMENT: To the Fundação de Amparo à Pesquisa of the Mato Grosso state (CAPES/FAPEMAT) for financial support to the first author. To the Federal University of Mato Grosso (UFMT), Seed and Phytopathology Laboratories of Faculdade of Engenharia Agrícola, and Laboratory of Natural Products, of Faculdade of Química for development of research, analysis, and evaluation of results.

FUNDING: This work did not receive any specific grant from funding agencies in the public, commercial, or not-for-profit sectors.

CONFLICTS OF INTEREST: All authors declare that they have no conflict of interest.

ETHICAL APPROVAL: Not applicable.

AVAILABILITY OF DATA AND MATERIAL: The datasets generated and/or analyzed during the current study are available from the corresponding author on reasonable request.

AUTHORS' CONTRIBUTIONS: Conceptualization: Silva, A.M.P.; Data curation: Silva, A.M.P.; Camilli, E.C; Coelho, M.F;.B. Formal analysis: Silva, A.M.P.; Correa, A. R; Methodology: Silva, A.M.P.; Camilli, E.C; Kobayasti, Leimi; Pena, R.A.; Writing review \& editing: Silva, A.M.P.; Camilli, E.C; Arantes, C. R; Correa, A. R.

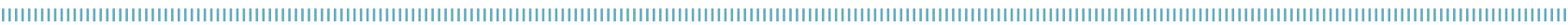
REFERENCES

ARIF, T.; BHOSALE, J.D.; KUMAR, N.; MANDAL, T.K.; BENDRE, R.S.; LAVEKAR, G.S.; DABUR, R. Natural products - antifungal agents derived from plants. Journal of Asian Natural Products Research, v. 1 1, n.7, p.62 1 638, 2009. https://doi.org/10.1080/10286020902942350

ARRUDA, W.; OLIVEIRA, G.M.C.; SILVA, I.G.D. Toxicity of the ethanol extract of Magonia pubescens on larvae Aedes aegypti. Revista da Sociedade Brasileira de Medicina Tropical, v.36, n. 1, p.17-25, 2003. https://doi.org/10.1590/S0037-86822003000100004

BEWLEY, J.D.; BLACK, M. Seeds: physiology of development and germination. New York: Plenum Press, 1994.

BRASIL. Ministério da Agricultura, Pecuária e Abastecimento. Regras para análise de sementes. Brasília: Mapa/ACS. 2009a.

BRASIL. Ministério da Agricultura, Pecuária e Abastecimento. Manual de análise sanitária de sementes. Brasília: Secretaria de Defesa Agropecuária/MAPA/ACS, 2009b.
CAMILI, E.C.; BENATO, E.A.; PASCHOLATI, S.F.; CIA, P. Extrato de Agaricus blazei e Lentinula edodes no controle pós-colheita de mofo cinzento em uva 'Itália'. Pesquisa Aplicada ® Agrotecnologia, v.2, n.2, p.155-162, 2009.

CELANO, M.M.; MACHADO, J.C.; JACCOUD FILHO, D.S.; GUIMARAES, R.M. Avaliação do potencial de uso da restrição hídrica em teste de sanidade de sementes de trigo visando à detecção de fungos. Revista Brasileira de Sementes, v.34, n.4, p.613-618, 2012. https://doi.org/10.1590/ So $101-31222012000400012$

CHERIF, J.; DERBEL, N.; NAKKACH, M., BERGMANN, H.; JEMAL, F.; LAKHDAR, Z.B. Analysis of in vivo chlorophyll fluorescence spectra to monitor physiological state of tomato plants growing under zinc stress. Journal of Photochemistry and Photobiology $B$ : Biology, v.101, n.3, p.332-339, 2010. https://doi.org/10.1016/j. jphotobiol.2010.08.005 
DOMENE, M.P.; GLÓRIA, E.M.; BIAGI, J.D.; BENEDETTI, B.C.; MARTINS, L. Efeito do tratamento com óleos essenciais sobre a qualidade fisiológica e sanitária das sementes de milho (Zea mays). Arquivos do Instituto Biológico, São Paulo, v.83, e0072014, 2016. https://doi.org/10.1590/1808-1657000072014

DUKE, S.O.; CANTRELL, C.L.; MEEPAGALA, K.M.; WEDGE, D.E.; TABANCA, N.; SCHRADER, K.K. Natural toxins for use in pest management. Toxins (Basel), v.2, n.8, p. 1943-1962, 2010. https://doi.org/10.3390/toxins2081943

FERREIRA, D.F. SISVAR Versão 5.6 Build 86, 2015. Available from: http://www.dex.ufla.br/ danielff/programas/sisvar.html. Access on: Aug. 032018.

FRANÇA NETO, J.B.; KRZYZANOWSKI, F.C.; HANNING, A.A.; PÁDUA, G.P.; LORINI, I.; HANNING, F.A. Tecnologia da produção de semente de soja de alta qualidade. n. 380. Londrina: Embrapa Soja, 2016. p.82.

HENNING, A.A. Tratamento de sementes de soja. Embrapa Soja, Radar da Tecnologia. Available from: http://radar. cnpso.embrapa.br:8080/documents/10179/16724/ Tratamento+de+sementes+de+soja/ff6d84d5-1 e97-44c8bb8f-30acaa8d9078?version=1.0. Access on: Dec. 032018.

INSTITUTO NACIONAL DE METERIOLOGIA (INMET). Dados meteorológicos, 2018. Available from: http://www.inmet.gov. $\mathrm{br} /$ sonabra/pg_dspDadosCodigo_sim.php?QTkwMQ = =. Access on: Dec. 022018.

KRZYZANOWSKI, F.C.; VIEIRA, R.D; FRANÇA-NETO, J.B. (Eds.). Vigor de sementes: conceitos e testes. Londrina: ABRATES, 1999.

LAGROUH, F.; DAKKA, N.; BAKRI, Y. The antifungal activity of Moroccan plants and the mechanism of action of secondary metabolites from plants. Journal de Mycologie Médicale, v.27, n.3, p.303-311, 2017. https://doi.org/10.1016/j. mycmed.2017.04.008

LINS, S.R.O.; OLIVEIRA, S.M.A.; XAVIER, H.S.; RANDAU, K.P. Prospecção fitoquímica de extratos de plantas e controle da podridão peduncular em manga. Revista Brasileira de Ciências Agrárias, v.7, n.1, p.97-103, 2012. https://doi.org/10.5039/ agraria.v7i1a1633

LOPES, A.S. Manual internacional de fertilidade do solo. $2^{\mathrm{a}}$ ed. Piracicaba: Patafos, 1998.

MAGUIRE, J.D. Speed of germination aid in selection and evaluation for seedling emergence and vigor. Crop Science, Madison, v.2, n.2, p.176-177, 1962

MALAVOLTA, E.; VITTI, G.C.; OLIVEIRA, S.A. Avaliação do estado nutricional das plantas: princípios e aplicações. Piracicaba: POTAFÓS, 1997.

MARCOS FILHO, J. Germinação de sementes. In: CÍCERO, S.M.; MARCOS-FILHO, J. \& SILVA, W.S. Atualização em produção de sementes. Piracicaba: Fundação Cargill, 1986. p.11-39.
MARCOS FILHO, J. Teste de envelhecimento acelerado. In: VIEIRA, R.D.; CARVALHO, N.M. (Ed.). Testes de vigor em sementes. Jaboticabal: Funep, 1994. p.133-150.

MATOS, F.J.A. Introdução à fitoquímica experimental. Fortaleza: Editora da Universidade Federal do Ceará, 2009.

MEDEIROS, J.G.F.; ARAUJO, N.; ADERSON, C.; MEDEIROS, D.S.; NASCIMENTO, L.C.; ALVES, E.U. Extratos vegetais no controle de patógenos em sementes de Pterogyne nitens Tul. Floresta e Ambiente, Seropédica, v.20, n.3, p.384-390, 2013. https://doi. org/10.4322/floram.2013.029

MONTEIRO, C. S.; KALLUF, V.; PENTEADO, P.T.; WASZCZYNSKYJ, N.; FREITAS, R.; STERTZ, S. C. Caracterização química do cogumelo Agaricus blasei Murril. Revista Visão Acadêmica, Curitiba, v.6, n.1, p.7-13, 2005. https://doi.org/10.5380/acd.v6i 1.581

NAKAGAWA, J. Testes de vigor baseados no desempenho de plântulas. In: KRZYZANOWSKY, F.C.; VIEIRA, R.D.; FRANÇA-NETO, L.B. Vigor de sementes: conceitos e testes. Londrina: ABRATES, 1999. p.2.1-2.24.

OLIVEIRA, C.M.R.; IACOMINI, M.; ALQUINI, Y.; GORIN, P.A.J. Microscopic and NMR analysis of the external coat from seeds of Magonia pubescens. New Phytologist, v. 152, n.3, p.501-509, 2001. https://doi.org/10.1046/j.0028-646X.2001.00279.x

SILVA, H.H.G.D.; SILVA, I.G.D.; SANTOS, R.M.G.D.; RODRIGUES FILHO, E.; ELIAS, C.N. Larvicidal activity of tannins isolated of Magonia pubescens St. Hil. (Sapindaceae) against Aedes aegypti (Diptera, Culicidae). Revista da Sociedade Brasileira de Medicina Tropical, v.37, n.5, p.396-399, 2004. https://doi.org/10.1590/ S0037-86822004000500005

SILVA, K.R.G.; VILLELA, F.A. Pré-hidratação e avaliação do potencial fisiológico de sementes de soja. Revista Brasileira de Sementes, Londrina, v.33, n.2, p.331-345, 2011 . https://doi. org/10.1590/SO101-31222011000200016

STANGARLIN, J.R.; KUHN, O.J.; TOLEDO, M.V.; PORTZ, R.L.; PASCHOLATI, S.F. A defesa vegetal contra fitopatógenos. Scientia Agraria Paranaensis, v.10, n.1, p.18-46, 2011 . http://dx.doi. org/10.18188/sap.v10i 1.5268

TAVALLALI, V.; RAHEMI, M.; MAFTOUN, M.; VAEZPOUR, M. Zinc influence and salt stress on photosynthesis, water realtions, and carbonic anhydrase activity in pistachio. Scientia Horticulturae, v.123, n.123, p.272-279, 2009. https://doi.org/10.1016/j. scienta.2009.09.006

VIGNOLO, G.K.; PICOLOTTO, L.; GONÇALVES, M.A.; PEREIRA, I.S.; ANTUNES, L.E.C. Presença de folhas no enraizamento de estacas de amoreira-preta. Ciência Rural, Santa Maria, v.44, n.3, p.467-472, 2014. https://doi.org/10.1590/S0103-84782014000300013

ZIEGLER, P. Carbohydrate degradation during germination. In: KIGEL, J.; GALILI, G. (Ed.). Seed development and germination. New York: Marcel Dekker, 1995. p.447-474. 